\title{
Pengembangan media pembelajaran interaktif berbasis flash dengan pendekatan kontekstual pada materi jarak, waktu, dan kecepatan untuk siswa SD kelas V semester I
}

\author{
Ariyan Pradana, Ety Tejo Dwi Cahyowati*, Darmawan Satyananda \\ Universitas Negeri Malang, Jl. Semarang No. 5 Malang, Jawa Timur, Indonesia \\ *Penulis korespondensi, Surel: ety.tejo.fmipa@um.ac.id
}

Paper received: 01-12-2021; revised: 15-12-2021; accepted: 31-12-2021

\begin{abstract}
Abstrak
Peningkatan kualitas pendidikan dapat dicapai dengan menciptakan terobosan dalam bidang pembelajaran, salah satunya adalah dengan menciptakan media pembelajaran. Tujuan dari penelitian ini adalah menghasilkan media pembelajaran interaktif dengan pendekatan kontekstual untuk siswa SD pada pokok bahasan jarak, waktu, dan kecepatan. Pengembangan media pembelajaran interaktif ini mengadaptasi model pengembangan Luther (Sutopo, 2003) dan Purwanto (2004), yaitu model CADMAETR (Concept, Analysis, Design, Material collecting, Assembly, Evaluation, Testing, and Revition). Uji coba yang dilaksanakan adalah uji kevalidan dilakukan oleh satu orang dosen dan dua orang guru matematika, sedangkan uji kepraktisan dan uji keefektifan dilakukan oleh 6 orang siswa sebagai subjek uji coba. Berdasarkan analisis pengembangan didapatkan hasil bahwa media pembelajaran yang dikembangkan dinyatakan valid, praktis, dan efektif.
\end{abstract}

Kata kunci: media pembelajaran; jarak; waktu; kecepatan; kontekstual

\section{Pendahuluan}

Dalam pembelajaran matematika, siswa diharapkan akan belajar tentang hal-hal yang berkaitan dengan penalaran, yaitu alasan-alasan logis yang dapat diterima oleh akal (Shadiq, 2004). Kemampuan bernalar inilah yang membedakan manusia dengan makhluk hidup lainnya. Kemampuan tersebut dapat ditularkan dari satu generasi ke generasi berikutnya melalui pendidikan, atau yang sekarang biasa disebut dengan proses pembelajaran di sekolah. Hal itu sejalan dengan Standar Isi Mata Pelajaran Matematika (Depdiknas, 2006) bahwa mata pelajaran matematika diberikan kepada semua peserta didik mulai dari sekolah dasar untuk membekali peserta didik dengan kemampuan berpikir logis, analitis, sistematis, kritis, dan kreatif, serta kemampuan bekerja sama. Kompetensi tersebut diperlukan agar peserta didik dapat memiliki kemampuan memperoleh, mengelola, dan memanfaatkan informasi untuk bertahan hidup pada keadaan yang selalu berubah, tidak pasti, dan kompetitif.

Salah satu bahasan pokok matematika yang diajarkan di sekolah adalah tentang pengukuran, yaitu materi Jarak, Waktu, dan Kecepatan. Sebenarnya, materi jarak, waktu, dan kecepatan merupakan salah satu topik yang menarik dalam pembelajaran di sekolah. Materi ini diajarkan dalam mata pelajaran matematika Sekolah Dasar kelas V semester 1. Dikatakan menarik karena secara tidak langsung, siswa sebenarnya telah melakukan aktivitas seharihari yang berhubungan langsung dengan jarak, waktu, dan kecepatan. Jarak perjalanan yang ditempuh siswa ke sekolah, waktu yang dibutuhkan siswa untuk sampai ke sekolah, dan berapa kecepatan kendaraan yang digunakan siswa adalah sebagian kecil kejadian yang tidak asing bagi siswa, akan tetapi siswa belum terlalu menyadari apa arti dan hubungan dari ketiga hal tersebut. Pertimbangan lain pemilihan materi jarak, waktu, dan kecepatan adalah 
karena sering ditemui siswa yang kesulitan ketika memperoleh materi tersebut. Kebanyakan mereka mengalami kesulitan dalam mencari hubungan antara jarak, waktu, dan kecepatan.

Berdasarkan hasil diskusi dengan beberapa guru Sekolah Dasar, diperoleh informasi bahwa selama ini guru hanya memberikan rumus hubungan jarak, waktu, dan kecepatan secara langsung kepada siswa SD. Hal ini cenderung menjadikan siswa menghafal rumus tanpa makna. Menanggapi hal tersebut, diharapkan adanya sebuah bahan ajar yang dapat membantu siswa dalam belajar matematika yaitu bahan ajar yang dapat menciptakan pembelajaran yang bermakna bagi siswa dengan cara mengalami sendiri apa yang dipelajarinya bukan sekedar menghafal.

Berdasarkan hal-hal tersebut di atas, maka perlu kiranya diberikan suatu pendekatan pembelajaran yang menarik kepada siswa yang dapat membantu dalam pembelajaran matematika, terutama yang berkaitan dengan permasalahan jarak, waktu, dan kecepatan, kasus-kasus terkait serta solusi pemecahannya. Pendekatan pembelajaran yang dimaksud adalah pendekatan pembelajaran dengan melibatkan peserta didik secara aktif yang akan memberikan hasil belajar yang efektif, yaitu pendekatan kontekstual. Menurut Nurhadi (2004) pembelajaran yang terjadi di sekolah selama ini hanya berorientasi pada target penguasaan materi sehingga terbukti berhasil dalam kompetisi 'mengingat' jangka pendek, tetapi gagal dalam membekali anak memecahkan persoalan dalam kehidupan jangka panjang. Pendekatan kontekstual adalah pendekatan pengajaran yang dari karakteristiknya memenuhi harapan itu, yaitu mampu menciptakan pembelajaran bermakna bagi peserta didik dan membekalinya untuk memecahkan persoalan.

Depdiknas (2002) menyatakan pembelajaran kontekstual (Contextual Teaching and Learning) merupakan proses belajar yang diawali dengan guru mengaitkan materi yang diajarkan dengan situasi dunia nyata peserta didik dan mendorong peserta didik membuat hubungan-hubungan antara pengetahuan yang dimilikinya dengan penerapannya dalam kehidupan sehari-hari. Dengan demikian, peserta didik belajar dengan mengalami sendiri dan mengkonstruksi pengetahuan kemudian memberi makna pada proses belajar tersebut. Dengan mengetahui makna belajar peserta didik dapat menerapkan pengetahuan yang dimiliki dan menerapkannya dalam kehidupan sehari-hari.

Pembelajaran kontekstual lebih memfokuskan pada proses belajar peserta didik melalui kegiatan atau peristiwa yang pernah dialami sendiri sehingga peserta didik tidak hanya mengetahui dan mengingat. Pembelajaran dengan pendekatan kontekstual tidak hanya berorientasi pada penguasaan materi saja melainkan proses pembelajaran yang diutamakan agar dapat membekali peserta didik untuk dapat memecahkan masalah dan menerapkannya dalam kehidupan mereka.

Sementara itu, bahan ajar yang selama ini digunakan untuk materi jarak, waktu dan kecepatan kebanyakan berupa buku paket-buku paket yang kurang bisa mengembangkan pemahaman siswa khususnya hubungan jarak, waktu, dan kecepatan. Atas dasar inilah perlu kiranya membuat suatu bahan ajar alternatif yang bisa menarik minat siswa dalam belajar sekaligus mengembangkan pemahaman siswa, yaitu bahan ajar Multimedia Pembelajaran Interaktif (MPI).

Multimedia Pembelajaran Interaktif (MPI) merupakan salah satu jenis program komputer e-learning yang memiliki fasilitas-fasilitas untuk digunakan dalam dunia 
pendidikan. MPI mampu menyajikan informasi tentang materi pelajaran, membuat penilaian evaluasi, dan memberikan animasi-animasi menarik dalam penyampaian materi sehingga siswa tidak mudah jenuh dalam menerima suatu materi.

MPI yang dikembangkan nantinya diharapkan mampu menciptakan suasana belajar yang tidak membosankan dengan cara memberikan beberapa animasi interaktif yang akan membantu siswa dalam memahami materi sekaligus bisa menjadi bahan ajar alternatif bagi guru-guru di sekolah. Adapun tujuan dari penelitian ini adalah menghasilkan Media Pembelajaran Interaktif (MPI) untuk jarak, waktu, dan kecepatan dengan pendekatan kontekstual.

\section{Metode}

Penelitian ini adalah penelitian pengembangan yang produknya berupa Media Pembelajaran Interaktif (LKS) berbasis Flash dengan pendekatan kontekstual pada pokok bahasan jarak, waktu, dan kecepatan. Model pengembangan bahan ajar ini mengadaptasi pada model pengembangan bahan ajar dari Luther yaitu model CADMAETR (Concept, Analysis, Design, Material collecting, Assembly, Evaluation, Testing, and Revision).

Pada penelitian ini, produk yang telah dikembangkan oleh peneliti akan diuji tingkat kevalidan, kepraktisan, dan keefektifannya. Uji kevalidan dilakukan bertujuan untuk melihat apakah produk yang telah dikembangkan oleh peneliti telah sesuai dengan kriteria MPI dan sesuai dengan kompetensi yang ingin dicapai dalam pembelajaran. Uji kepraktisan dilakukan untuk melihat sejauh mana produk yang dihasilkan praktis untuk digunakan siswa atau tidak. Sedangkan uji keefektifan dilakukan untuk melihat sejauh mana produk yang dihasilkan mampu membantu siswa belajar materi yang diajarkan.

Uji kevalidan menggunakan angket validasi dan dilakukan oleh 1 orang dosen matematika dan 2 orang guru matematika yang telah berpengalaman di bidangnya. Uji kepraktisan juga menggunakan angket validasi dan dilakukan oleh 6 siswa yang telah dipilih sebagai subjek uji coba. Uji keefektifan dilakukan dengan melihat hasil pengerjaan MPI oleh siswa. MPI dikatakan efektif jika nilai rata-rata hasil pengerjaan siswa lebih dari 75, yang merupakan KKM di SD Negeri Karangbesuki 3 Malang.

Teknik analisis data hasil uji kevalidan dan kepraktisan yang digunakan mengadaptasi dari teknik analisis Purwanto (2005) yaitu :

$$
P=\frac{\sum_{i=1}^{n} x_{i}}{n \times k} \times 100 \%
$$

Dengan,

$\mathrm{P} \quad=$ persentase penilaian.

$\sum_{i-1}^{n} x_{i}=$ menyatakan jumlah poin penilaian subyek coba 
$\begin{array}{ll}\mathrm{n} & =\text { menyatakan jumlah subyek coba } \\ \mathrm{k} & =\text { menyatakan skor penilaian tertinggi. }\end{array}$

Apabila data hasil validasi menunjukkan bahwa persentase yang dicapai kurang dari 55\% maka MPI perlu direvisi, selain itu juga memperhatikan komentar dan saran yang diberikan oleh subjek coba.

Untuk analisis hasil pengerjaan latihan soal pada media pembelajaran oleh peserta didik, minimal 3 peserta didik hasil pengerjaannya memenuhi standar ketuntasan belajar berdasarkan ketuntasan belajar dari sekolah yaitu $75 \%$ dari nilai tertinggi. Maka dapat disimpulkan bahwa peserta didik telah menguasai materi dalam media pembelajaran tersebut, sehingga media dapat dikatakan efektif. Sedangkan untuk analisis angket oleh peserta didik jika lebih dari 50\% peserta didik memberi tanggapan sama maka hal ini dijadikan dasar untuk melakukan revisi atau tidak.

\section{Hasil dan Pembahasan}

\subsection{Hasil}

Media pembelajaran yang telah dikembangkan oleh pengembang adalah Media Pembelajaran Interaktif (MPI) berbasis Flash untuk kelas V SD dengan materi jarak, waktu, dan kecepatan. MPI yang dihasilkan terdiri atas halaman Layout pembuka (memuat judul, jenjang pendidikan, materi pokok, logo media, lembaga penyusun, dan tombol interaktif "START" untuk mulai menjalankan media pembelajaran), halaman inti (memuat tombol interaktif untuk dipilih oleh siswa), dan tombol "EXIT" untuk keluar dari program media pembelajaran. Adapun halaman inti media berisi menu home (memuat ucapan selamat datang disertai animasi menarik), kompetensi (memuat standar kompetensi dan kompetensi dasar yang harus dikuasai oleh siswa), materi (memuat materi pokok dengan penyajian materi menggunakan strategi kontekstual REACT), evaluasi (memuat soal-soal evaluasi beserta skor penilaian untuk siswa), dan petunjuk (memuat petunjuk bagi siswa untuk menjalankan program media pembelajaran).

Pelaksanaan uji coba produk MPI yang dikembangkan dilaksanakan dalam dua tahap, yaitu tahap pertama uji coba kepada 1 orang dosen matematika sebagai validator ahli dan 2 orang guru sebagai praktisi lapangan, dan pada tahap kedua uji coba kepada 6 orang siswa kelas 5 semester 1 SD Negeri Karangbesuki 3 Malang. Adapun uji coba produk yang dilakukan pengembang adalah uji kevalidan, uji kepraktisan, dan uji keefektifan.

Uji kevalidan produk dilakukan pada tahap uji coba pertama oleh 1 orang dosen matematika dan 2 orang guru SD dengan menggunakan angket validasi produk. Hasil uji kevalidan disajikan sebagai berikut :

Tabel 1. Analisis Hasil Uji Kevalidan

\begin{tabular}{lllll}
\hline No. & Aspek yang dinilai & $\begin{array}{l}\text { Skor } \\
\text { kevalidan }\end{array}$ & $\begin{array}{l}\text { Kriteria } \\
\text { kevalidan }\end{array}$ & Keterangan \\
\hline 1. & Konten Media Pembelajaran & $87,5 \%$ & Sangat Valid & Tidak perlu revisi \\
\hline
\end{tabular}




\begin{tabular}{|c|c|c|c|c|}
\hline 2. & $\begin{array}{l}\text { Presentasi dan Organisasi Konten } \\
\text { Media Pembelajaran }\end{array}$ & $87,5 \%$ & Sangat Valid & Tidak perlu revisi \\
\hline 3. & Pembelajaran & $89,1 \%$ & Sangat Valid & Tidak perlu revisi \\
\hline
\end{tabular}

Secara keseluruhan aspek terhadap MPI yang telah dikembangkan, diperoleh skor kevalidan sebesar 88,1 \% dan berada pada kriteria kevalidan sangat valid. Jadi, dapat disimpulkan bahwa MPI yang telah dikembangkan sangat valid dan tidak perlu dilakukan revisi. Namun demikian, peneliti tetap melakukan revisi di beberapa bagian sebagai upaya penyempurnaan MPI yang dikembangkan.

Sementara itu, uji kepraktisan produk pengembangan dilakukan pada 6 siswa yang telah dipilih oleh guru sebagai subjek uji coba. Uji kepraktisan dilakukan setelah semua subjek coba telah mengerjakan seluruh MPI yang dikembangkan oleh pengembang. Uji kepraktisan ini dilakukan setelah uji kevalidan dan revisi produk berdasarkan angket uji kevalidan dan catatan atau saran dari validator. Secara keseluruhan skor kepraktisan yang diperoleh pada uji kepraktisan oleh subjek uji kepraktisan adalah 88,6 \%. Skor ini menunjukkan bahwa MPI yang dikembangkan praktis dan bisa diterapkan dan digunakan di lapangan.

Uji keefektifan produk pengembangan dilakukan pada 6 siswa yang telah dipilih oleh guru sebagai subjek uji coba. Uji keefektifan dilakukan dengan meminta siswa mengerjakan soal evaluasi pada MPI setelah siswa menyelesaikan materi sampai selesai. Nilai kefektifan dilihat dari hasil pengerjaan siswa. Uji keefektifan ini dilakukan setelah uji kevalidan dan revisi produk berdasarkan angket uji kevalidan dancatatan atau saran dari validator. Untuk uji keefektifan, diperoleh data nilai rata-rata siswa dalam mengerjakan evaluasi MPI adalah 88,3. Hal tersebut menunjukkan bahwa siswa tuntas dalam belajar materi jarak, waktu, dan kecepatan. Sehingga dapat disimpulkan bahwa MPI efektif dan dapat digunakan dalam pembelajaran di kelas. Namun, tingkat kesukaran soal perlu dikaji ulang.

Berdasarkan catatan dan saran yang diperoleh dari validator yang meliputi dosen dan guru matematika serta subjek uji coba akan dilakukan perbaikan produk.

Tabel 2. Catatan/saran dosen dan guru matematika serta subjek uji coba sebagai dasar perbaikan yang dilakukan pada LKS

\begin{tabular}{|c|l|l|}
\hline No. & Catatan/Saran & Perbaikan \\
\hline 1. & $\begin{array}{l}\text { Tombol PLAY cukup muncul sekali dan } \\
\text { setelah diklik muncul penguatan }\end{array}$ & $\begin{array}{l}\text { Setelah tombol PLAY diklik, tombol } \\
\text { hilang dan diganti dengan } \\
\text { keterangan }\end{array}$ \\
\hline 2. & Perlu tambahan soal pada bagian otak-atik & $\begin{array}{l}\text { Memberi tambahan soal pada bagian } \\
\text { otak-atik }\end{array}$ \\
\hline 3. & $\begin{array}{l}\text { Pada bagian kupas materi, kalimat } \\
\text { penegasan materi diganti agar tidak menjadi } \\
\text { ambigu }\end{array}$ & $\begin{array}{l}\text { Mengganti kata-kata pada penegasan } \\
\text { materi sehingga lebih jelas dan tidak } \\
\text { ambigu }\end{array}$ \\
\hline 4. & $\begin{array}{l}\text { Pada bagian evaluasi, pilihan ganda pada } \\
\text { suatu nomor hanya bisa dipilih/diklik } \\
\text { pada slide soal yang sedang ditampilkan }\end{array}$ & $\begin{array}{l}\text { Pilihan ganda pada suatu nomor } \\
\text { hanya bisa dipilih jika soal tersebut } \\
\text { yang aktif di halaman }\end{array}$ \\
\hline
\end{tabular}


Berdasarkan analisis yang telah dilakukan di atas, dapat disimpulkan bahwa MPI yang dikembangkan telah mencapai kriteria valid, praktis, dan efektif.

\subsection{Pembahasan}

Media Pembelajaran Interaktif (MPI) yang berdasarkan tahapan pembelajaran strategi REACT setelah dilakukan revisi dijelaskan sebagai berikut :

3.2.1. Relating : pada tahap ini siswa diharapkan dapat mengaitkan pengetahuan (apa yang akan dipelajari) dengan kehidupan sehari-hari. Hal ini dapat dijadikan motivasi bagi siswa. Pada MPI ini, tahap relating ditunjukkan pada bagian submateri ayo belajar dan siapa dapat.

ayo belajar, diberikan stimulus berupa gambar speedometer yang nantinya akan memancing motivasi siswa untuk mempelajari konsep kecepatan.

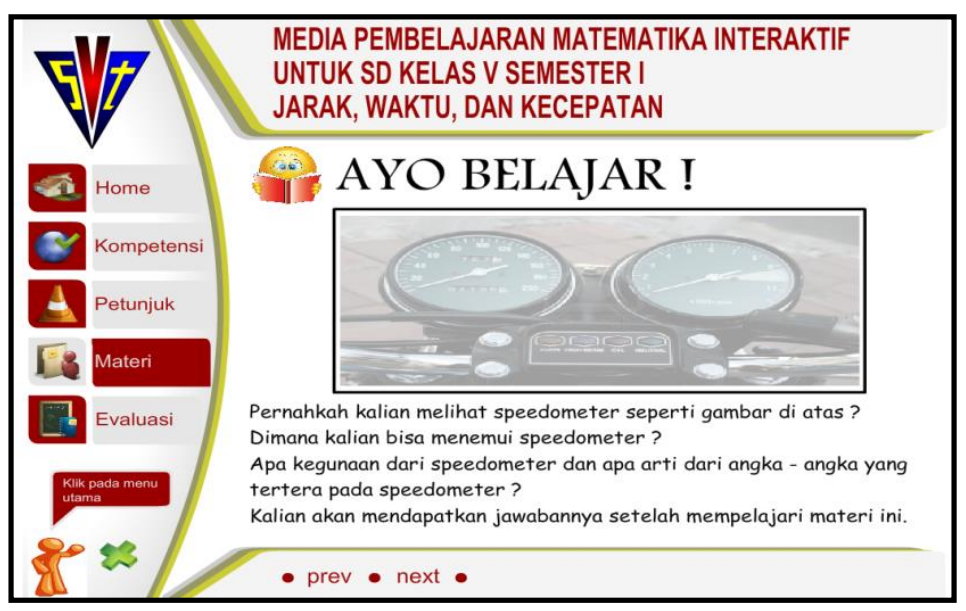

siapa dapat, memuat aktivitas yang memancing kemampuan siswa yang sudah diperoleh sebelumnya.

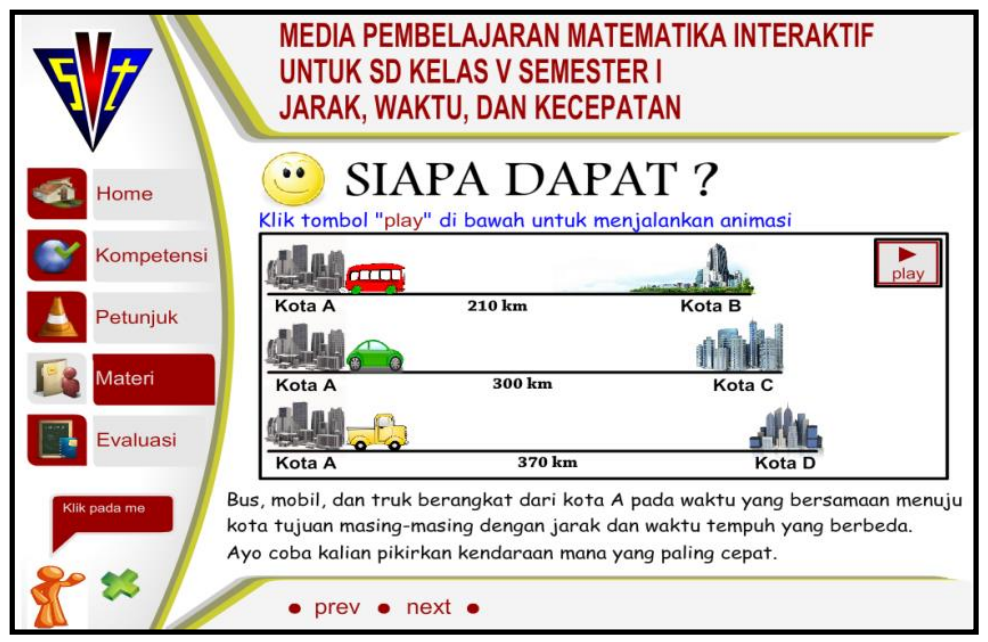


3.2.2. Experiencing : memuat kegiatan eksplorasi, penemuan dan pengkonstruksian konsep. Pada MPI ini, tahap experiencing ditunjukkan pada submateri otak-atik dan kupas materi.

otak-atik, siswa diharapkan mengalami sendiri proses menemukan konsep kecepatan.

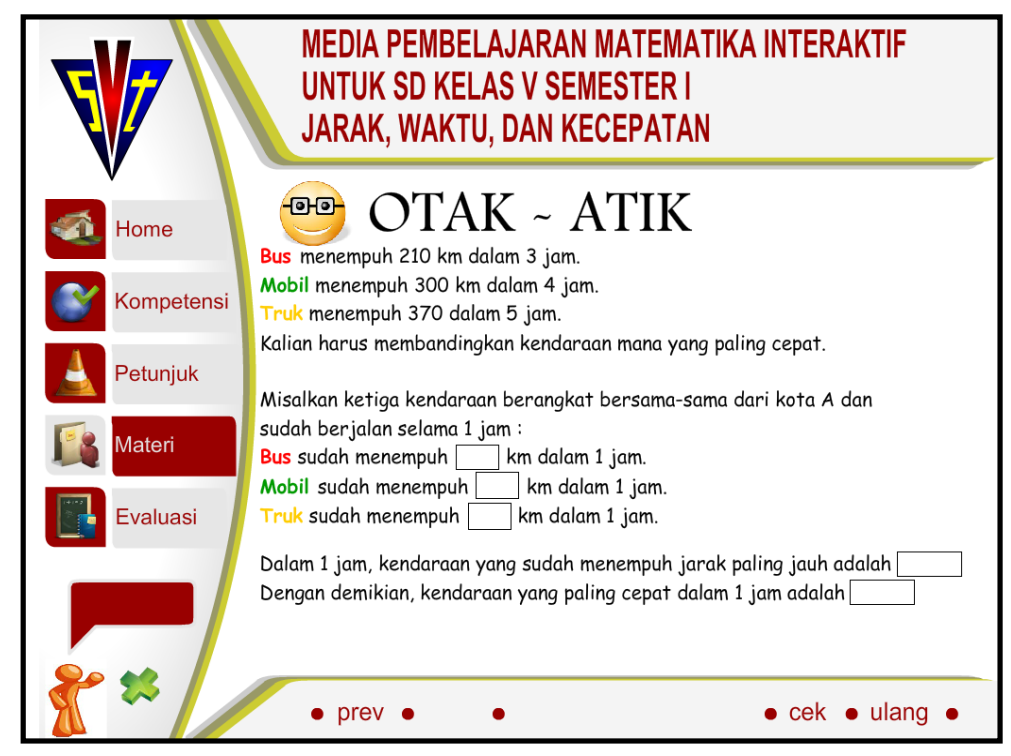

kupas materi, siswa diharapkan sudah bisa menemukan dan mengkonstruksi sendiri konsep kecepatan.

MEDIA PEMBELAJARAN MATEMATIKA INTERAKTIF
UNTUK SD KELAS V SEMESTER I
JARAK, WAKTU, DAN KECEPATAN


3.2.3. Applying : pada bagian ini siswa dapat menerapkan konsep dan pengetahuan yang sudah diperoleh sebelumnya. Pada MPI ini, tahap applying ditunjukkan pada submateri kasus liburan dan kasus wisata.

kasus liburan, kasus wisata, ayo pecahkan kasusnya, dan refleksi siswa diberikan soal cerita yang nantinya diharapkan bisa diselesaikan dengan menerapkan konsep kecepatan yang sudah dipelajari.

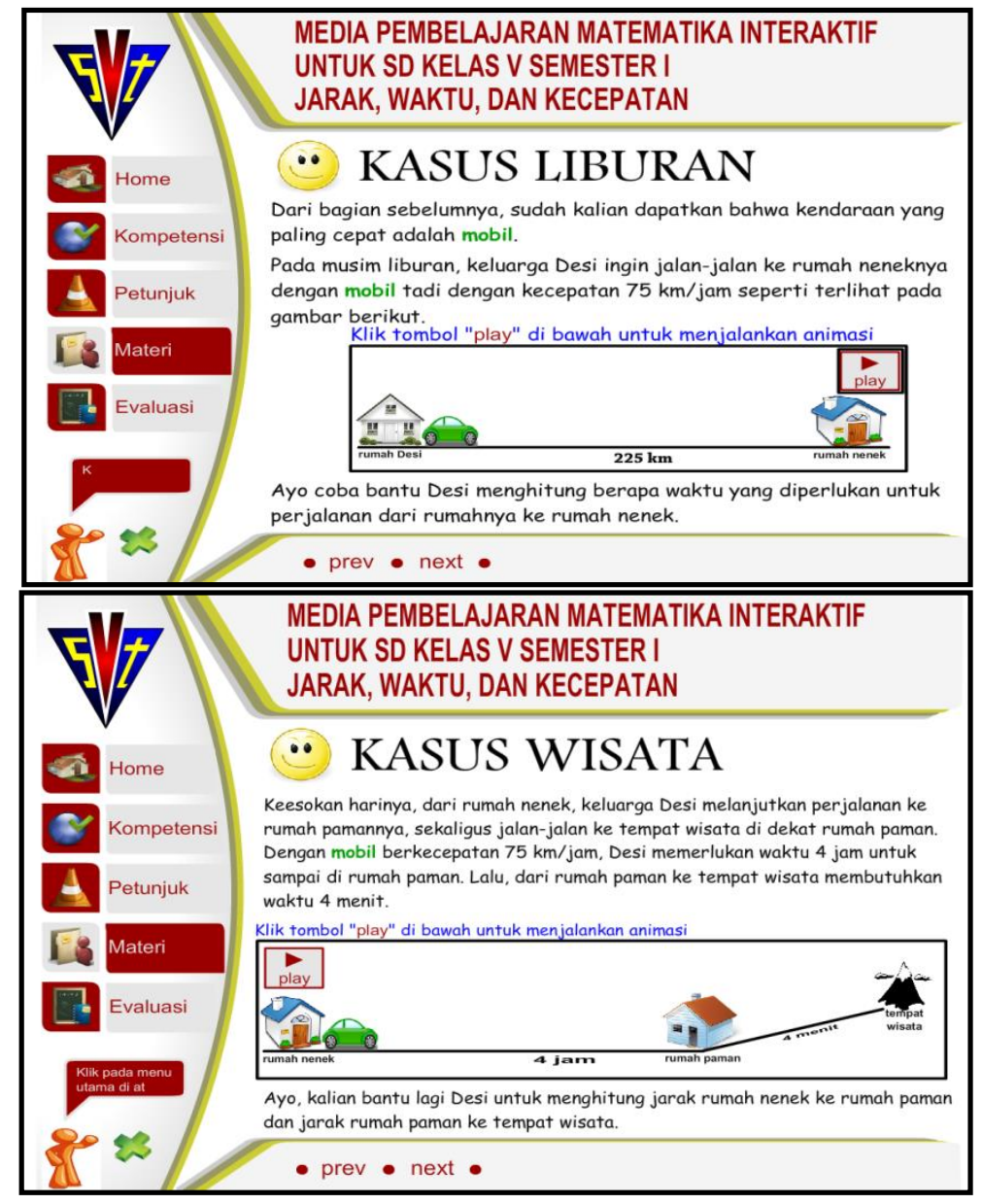

ayo pecahkan kasusnya dan refleksi, siswa menyelesaikan soal cerita dengan menerapkan konsep hubungan antarajarak, waktu, dan kecepatan.

MEDIA PEMBELAJARAN MATEMATIKA INTERAKTIF
UNTUK SD KELAS V SEMESTER I
JARAK, WAKTU, DAN KECEPATAN




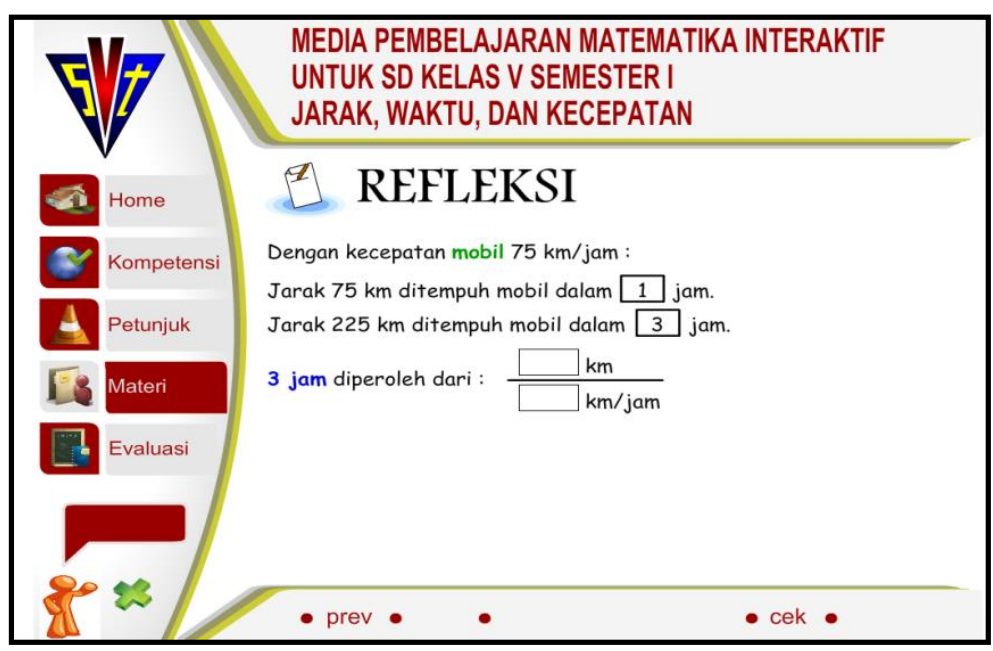

latihan soal, dengan mengerjakan latihan soal diharapkan siswa dapat menerapkan konsep dan pengetahuan yang sudah diperoleh sebelumnya.

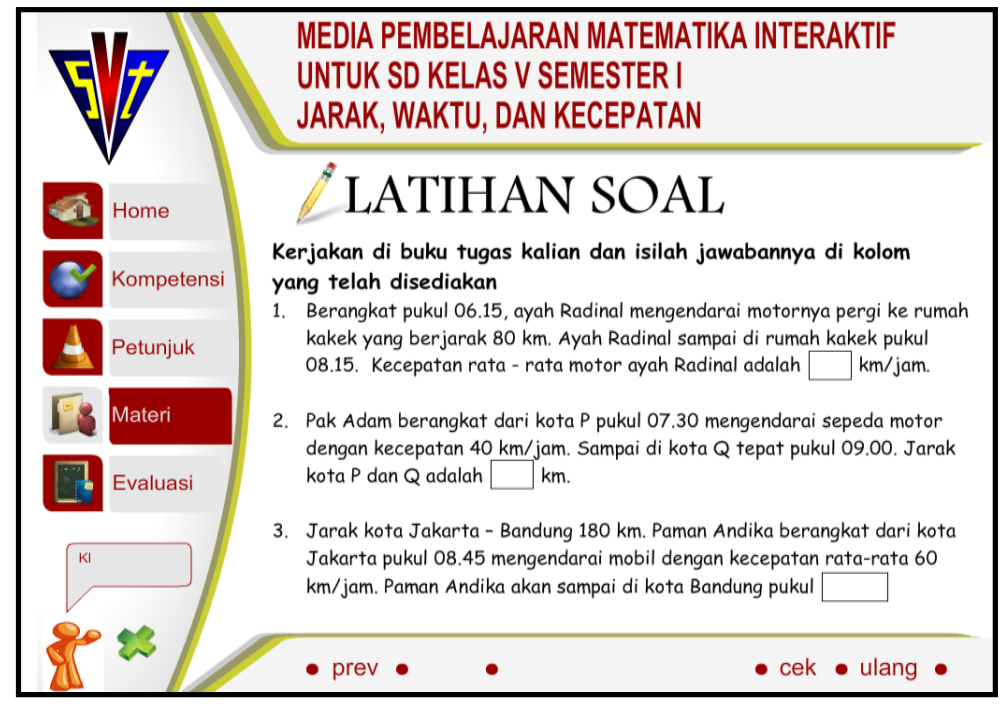

3.2.4. Cooperating : pada tahap ini siswa diharapkan bisa bekerja sama dalam menyelesaikan permasalahan yang diberikan. Pada MPI ini tahap cooperating ditunjukkan pada menu PETUNJUK. Diberikan keterangan bahwa pengerjaan MPI ini dilakukan secara berkelompok dengan masing-masing kelompok beranggotakan 4 orang, kecuali untuk EVALUASI yang harus dikerjakan secara individu.

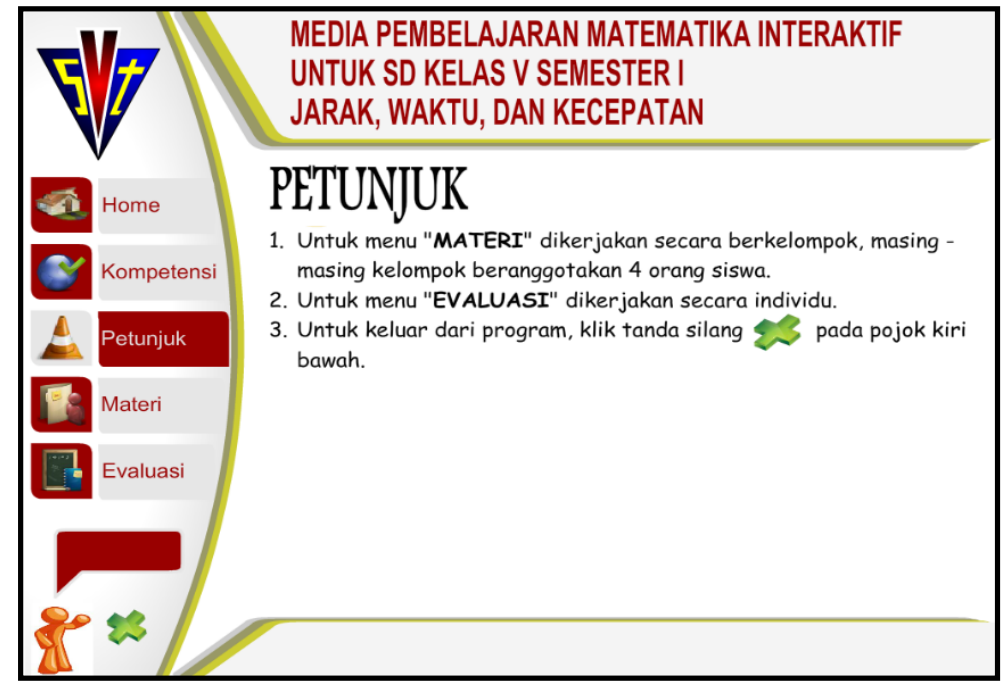


3.2.5. Transferring : pada bagian tantangan 1 dan $\mathbf{2}$ siswa dihadapkan pada situasi baru yaitu mencari konsep tentang hubungan jarak, waktu, dan kecepatan pada kasus dua kendaraan yang saling berpapasan dan saling menyusul. Pada MPI ini tahap transferring ditunjukkan pada submateri tantangan 1 dan 2.

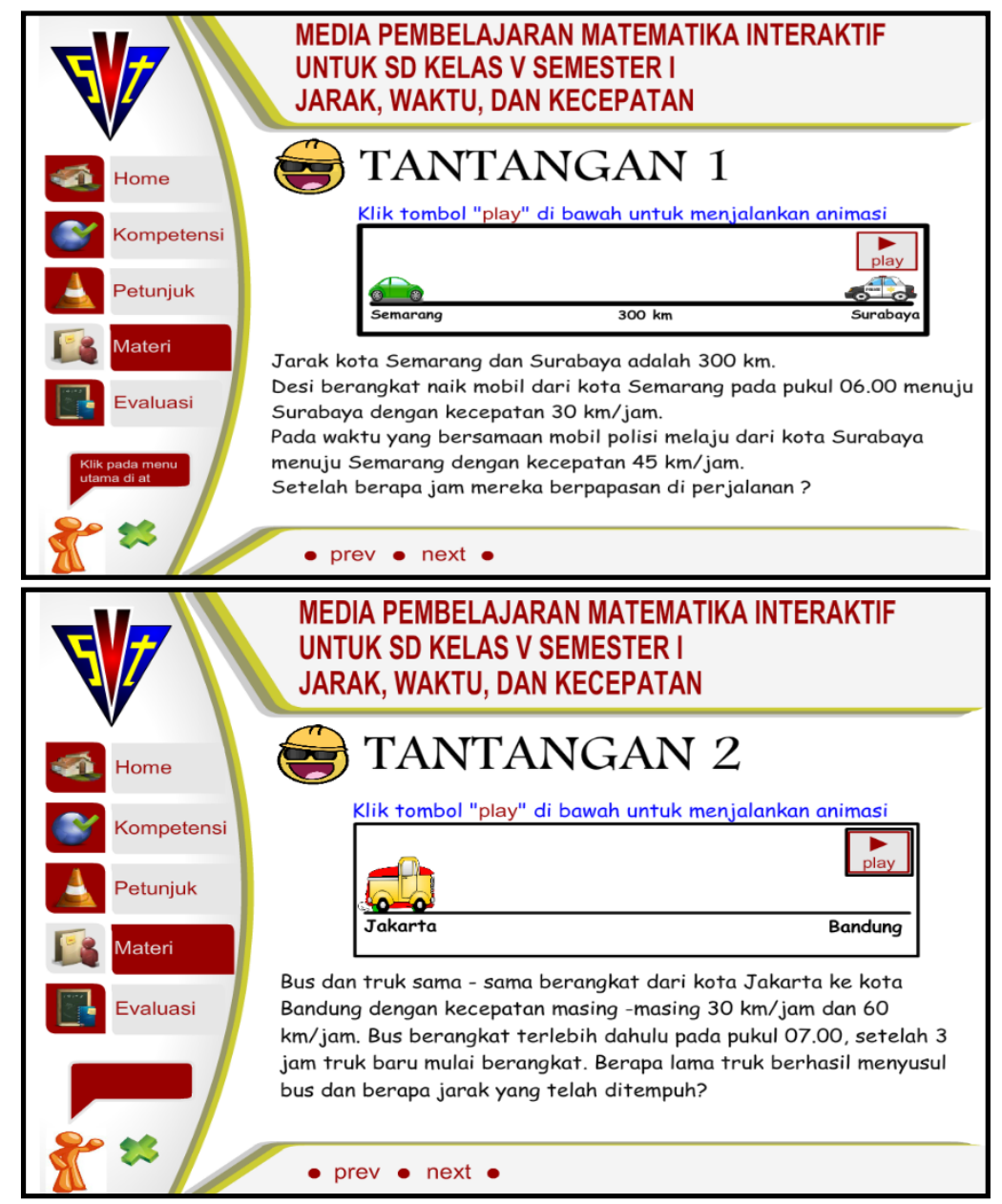

\section{Simpulan}

\subsection{Kesimpulan}

Berdasarkan hasil validasi yang meliputi aspek konten media pembelajaran, aspek presentasi dan organisasi konten media, dan aspek pembelajaran dapat disimpulkan bahwa MPI yang telah dikembangkan sangat valid dengan persentase kevalidan 88,1\%. Sedangkan berdasarkan hasil validasi uji kepraktisan didapatkan persentase kepraktisan sebesar 88,6 \%, sehingga dapat disimpulkan bahwa MPI yang telah dikembangkan praktis untuk diterapkan dan digunakan di lapangan. Selain itu, hasil evaluasi subjek uji coba memenuhi standar ketuntasan minimum sehingga dapat disimpulkan bahwa MPI efektif membantu siswa dalam belajar tentang materi jarak, waktu, dan kecepatan. Secara keseluruhan dapat disimpulkan bahwa MPI yang dikembangkan telah valid, praktis, dan efektif serta layak digunakan sebagai alternatif media pembelajaran matematika pada materi jarak, waktu, dan kecepatan. 


\subsection{Saran}

Berdasarkan hasil penelitian yang telah dilakukan peneliti, maka saran yang direkomendasi oleh penulis, yaitu : (1) media pembelajaran yang telah dikembangkan dapat ditindaklanjuti dengan menggunakannya dalam pembelajaran di kelas, (2) ada tindak lanjut pengembangan MPI pada pokok bahasan lain sehingga dapat memperkaya sumber belajar siswa, (3) Melakukan uji coba produk pada kelompok besar untuk mendapatkan hasil yang lebih meyakinkan, (4) memberikan sistem penyimpanan sehingga media bisa lebih efisien untuk digunakan, dan (5) menambah soal-soal yang lebih banyak dan bervariasi. Selainitu, dibuat lebih interaktif dan lebih banyak animasi.

\section{Daftar Rujukan}

Depdiknas. (2006). Peraturan Pemerintah No 22 Tahun 2006 Tentang Standar Isi Kurikulum Tingkat Satuan Pendidikan Mata Pelajaran Matematika SD dan Madrasah Ibtidaiyah (MI). Jakarta: Depdiknas.

Fajar, S. (2004). Pemecahan Masalah, Penalaran dan Komunikasi. Yogyakarta: Widyaiswara PPPG Matematika Yogyakarta.

Nasional, D. P. (2002). Pendekatan kontekstual (contextual teaching and learning). Jakarta: Direktorat PLP.

Nurhadi. (2004). Kurikulum 2004 (Pertanyaan dan Jawaban). Jakarta: PT. Gramedia Widiasarana Indonesia.

Purwanto, S. (2004). Statistika Dasar. Jakarta: PT. Raja Grafindo Persada.

Sutopo, Ariesto Hadi. (2003). Animasi dengan Menggunakan Macromedia Flash Beserta ActionScript. Jakarta: Salemba Infotek. 